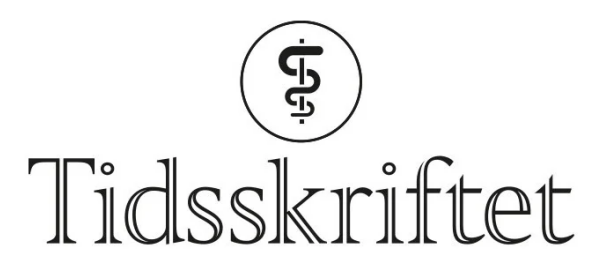

DEN NORSKE LEGEFORENING

\title{
Solarium er ikke sunt
}

\author{
KOMMENTARARTIKKEL
}

\section{MARIT B. VEIERØD}

Marit B. Veierød (f. 1962) er dr.philos. og professor i medisinsk statistikk ved Institutt for medisinske basalfag, Universitetet i Oslo.

Forfatter har fylt ut ICMJE-skjemaet og oppgir ingen interessekonflikter.

Email:m.b.veierod@medisin.uio.no

Institutt for medisinske basalfag

Universitetet i Oslo

\section{LILL TOVE N. NILSEN}

Lill Tove N. Nilsen (f. 1969) er dr.ing. og forsker ved Statens strålevern.

Forfatter har fylt ut ICMJE-skjemaet og oppgir ingen interessekonflikter.

Statens strålevern

\section{Mange nordmenn har bestilt sol- og badeferie i Syden. Bruk av solarium som en del av forberedelsene til ferien anbefales ikke.}

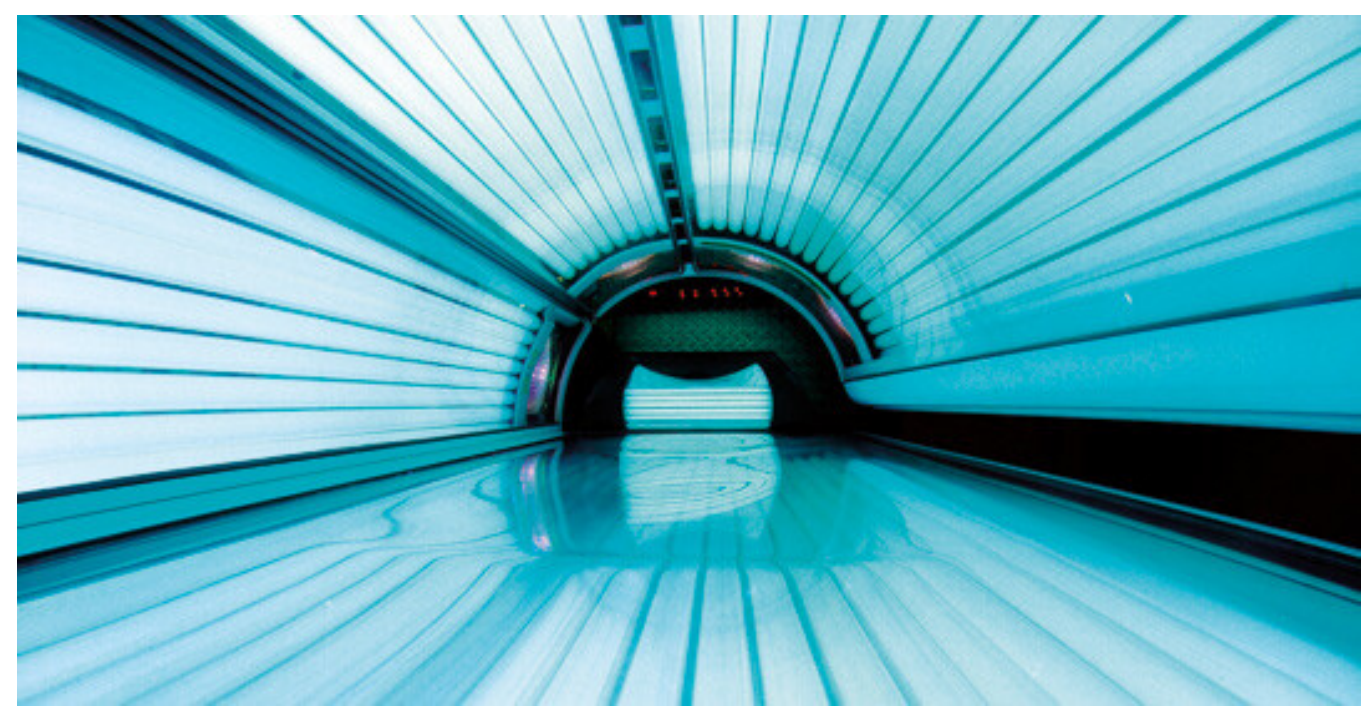

DPA/ NTB scanpix

Det er stor forskjell på soling i solarium og i naturlig sol. Ved bruk av solarium eksponeres nesten $100 \%$ av huden - mot vanligvis bare rundt 50 \% når man ligger på magen eller på ryggen i solen. Det er også stor forskjell i sammensetningen av de ultrafiolette strålene (UVstrålene) fra solarium og sol. Både sol og solarier gir UVB-stråling (bølgelengde 280-315 nm) 
og UVA-stråling (315-40o nm). Nylige målinger fra Statens strålevern av 194 solarier i 78 norske virksomheter viste at solarier i gjennomsnitt avgir dobbelt så mye UVB-stråling og rundt seks ganger mer UVA-stråling enn sommersol i Oslo (1). Det var stor variasjon mellom solariene; UVA-strålingen fra solariene var 3-26 ganger sterkere enn fra sommersol i Oslo.

\section{Effekter av UVA- og UVB-stråling}

Det skal omtrent 1 ooo ganger mer UVA-stråling enn UVB-stråling til for å gjøre oss solbrent (2). Tradisjonelt har UVB-strålene vært koblet til utvikling av hudkreft, mens UVA-strålene har vært sett på som mer ufarlige. UVA-strålene trenger imidlertid dypere ned i huden. Nyere forskning har vist at UVA-stråler kan være mer kreftfremkallende enn tidligere antatt (3). Både UVA- og UVB-stråling er nå klassifisert som kreftfremkallende (4.).

UVB-eksponering setter i gang pigmentproduksjon i huden og gir langvarig brunfarge. UVA-eksponering gir en umiddelbar bruning av pigment som allerede finnes i huden, men fargen forsvinner raskere. Solariene gir mest UVA-stråling og mer UVA-stråling enn vi kan få fra solen. Mange som bruker solarium før solferien, gjør dette for at huden skal tåle feriesolen bedre. Brunfarge fra UVA-stråling beskytter imidlertid ikke mot senere UVeksponering slik brunfarge fra UVB-stråling kan gjøre. UVB-stråling gir maksimalt en beskyttelsesfaktor mot solbrenthet på 2-3 $(5, \underline{6})$. Lys hud beskyttes også mot senere eksponering ved at repetert UV-eksponering gjør huden tykkere. UV-strålene får dermed lengre vei ned til de mer sårbare cellene $(7, \underline{8})$.

\section{Solariebruk anbefales ikke}

Bruk av solarier før solferien gir altså store doser UVA-stråling, og brunfargen fra UVAstrålingen har ingen beskyttende effekt i feriesolen. Et annet viktig argument mot forhåndsbruk av solarier er at dette gir økt samlet UV-eksponering. Risikoen for å bli solbrent under tilvenningen er også stor. Begge disse forholdene bidrar til å øke risikoen for hudkreft. Bruk av solarium før solferier anbefales derfor ikke.

Solariebruk er vanlig, ikke bare før solferier, men hele året, særlig blant ungdom. I forhold til andre farer ungdom utsettes for, er det lett å ignorere det faktum at bruk av solarium kan gi økt risiko for hudkreft - fordi hudkreft først inntreffer mange år etter soling. Fra 1. juli innføres 18-årsgrense på norske solarier, slik det allerede er innført i flere andre land. Dette er en klar melding om at soling i solarium ikke er trygt. I tillegg til økt risiko for hudkreft gir soling i solarium økt risiko for andre senskader, slik som for tidlig aldring av huden, pigmentforandringer i huden og malignt melanom i øyet $(\underline{6}, 9)$.

Publisert først på nett 30.5.2012

\section{LITTERATUR}

1. Nilsen LTN, Aalerud TN, Hannevik M et al. UVB and UVA irradiances from indoor tanning devices. Photochem Photobiol Sci 2011; 10:1129-36. [PubMed] [CrossRef]

2. Erythema reference action spectrum and standard erythema dose. ISO 17166:1999/CIE S oo7-1998. Vienna: CIE, 1999.

3. Tewari A, Sarkany RP, Young AR. UVA1 induces cyclobutane pyrimidine dimers but not 6-4 photoproducts in human skin in vivo. J Invest Dermatol 2012; 132:394-400. [PubMed] [CrossRef]

4. El Ghissassi F, Baan R, Straif K et al. A review of human carcinogens-part D: radiation. Lancet Oncol 2009; 10: 751-2. [PubMed] [CrossRef]

5. Miyamura Y, Coelho SG, Schlenz K et al. The deceptive nature of UVA tanning versus the modest protective effects of UVB tanning on human skin. Pigment Cell Melanoma Res 2011; 24: 136-47. [PubMed] [CrossRef] 
6. Opinion on Biological effects of ultraviolet radiation relevant to health with particular reference to sunbeds for cosmetic purposes (SCCP/0949/05). Brussel: European Commission, Health \& Consumer Protection Directorate-General, 2006.

ec.europa.eu/health/ph_risk/committees/04_sccp/docs/sccp_o_031b.pdf(12.3.2012).

7. Bech-Thomsen N, Wulf HC. Photoprotection due to pigmentation and epidermal thickness after repeated exposure to ultraviolet light and psoralen plus ultraviolet A therapy. Photodermatol Photoimmunol Photomed 1996; 11: 213-8. [PubMed] [CrossRef]

8. Lavker RM, Gerberick GF, Veres D et al. Cumulative effects from repeated exposures to suberythemal doses of UVB and UVA in human skin. J Am Acad Dermatol 1995; 32: 53-62. [PubMed] [CrossRef]

9. IARC Working Group Reports Vol. 1. Exposure to artificial UV radiation and skin cancer. Lyon: International Agency for Research on Cancer, 2006. www.iarc.fr/en/publications/pdfsonline/wrk/wrk1/ArtificialUVRad\&SkinCancer.pdf(13.3.2012).

Publisert: 12. juni 2012. Tidsskr Nor Legeforen. DOI: 10.4045/tidsskr.12.0401

Mottatt 28.3. 2012, første revisjon innsendt 7.5. 2012, godkjent 10.5. 2012. Medisinsk redaktør Petter Gjersvik.

(C) Tidsskrift for Den norske legeforening 2023. Lastet ned fra tidsskriftet.no 26. april 2023. 